\title{
Os provimentos de ofícios: a questão da propriedade no Antigo Regime português
}

\author{
Roberta Giannubilo Stumpf*
}

\section{RESUMO}

Este trabalho pretende analisar a concessão em propriedade de ofícios da monarquia portuguesa nos séculos XVII e XVIII. Com base em fontes de natureza diversa, deseja-se saber quais eram os cargos civis concedidos pelo rei segundo esta modalidade, assim como a sua expressão numérica na hierarquia administrativa. Considerando-se, ao mesmo tempo, o que se costuma definir como as normas e as práticas, analisar-se-ão os direitos dos titulares e seus descendentes para, finalmente, avaliar as mudanças administrativas propostas no centro político da monarquia na segunda metade do século XVIII, sobretudo no que se refere ao provimento dos ofícios civis na América portuguesa.

Palavras-chave: administração; monarquia portuguesa; propriedade de ofícios; Antigo Regime; América portuguesa.

\section{ABSTRACT}

This article focuses on the offices of the Portuguese monarchy that were given as "property" in the seventeenth and eighteenth centuries. Using different documental sources, the study intends to show which civil offices were provided by the king according to this property mode, and also its numerical expression in the administrative hierarchy. We examine the rights of office holders and their descendants in light of the usual definition of rules and practices. Finally, this paper assesses the proposed administrative changes in the political center in the second half of the eighteenth century, particularly the provision of civil offices in Portuguese America.

Keywords: administration; Portuguese monarchy; property of offices; Ancien Regime; Portuguese America. 
A história da administração portuguesa na Idade Média e no Antigo Regime tem merecido alguns estudos que nos ajudam a compreender a constituição do aparato administrativo no reino e sua extensão e organização nas possessôes lusas situadas nos continentes africano, asiático e americano. ${ }^{1}$ No entanto, excetuando os estudos de historiadores do direito, ${ }^{2}$ não são muitos os que dão destaque aos provimentos e às transmissóes dos ofícios, sobretudo em se tratando da historiografia mais recente. Longe de ser um tema residual, ou específico da história político-administrativa, a matéria proposta teve importantes implicaçóes na realidade socioeconômica, o que se poderá observar nas páginas seguintes, dedicadas, sobretudo, à patrimonialização dos ofícios ou, para se ser mais provocador, à "privatização" de alguns níveis da administração portuguesa no Antigo Regime.

Logo à partida, a questáo que se levanta diz respeito aos oficiais nomeados para representar e atuar em benefício dos interesses da monarquia e do bem comum e que, legalmente, podiam gozar das "honras, privilégios, liberdades, isençóes e franquezas..." inerentes aos cargos que ocupavam. Estamos a nos referir à organização e à atividade de um sistema que em muito difere da administração pública atual, pelo que é fundamental abandonar desde já qualquer tentativa de analisar este passado projetando nele, sem reservas, ideias do presente. Da mesma forma, não parece pertinente nos alongar no debate sobre a sobreposição dos interesses da monarquia e dos próprios oficiais, herdeira da teoria feudal dos cargos públicos, e sobre o quanto ela tornava este sistema ineficaz ou corrupto. ${ }^{3}$ Todavia, convém lembrar que se a concessão de privilégios a muitos oficiais conferia autoridade necessária ao exercício do mando, por outro lado, poderia acarretar alguns excessos ou abusos de poder. ${ }^{4}$ Desta forma, tanto no reino como nas diversas partes do império parece ter havido uma preocupação em fiscalizar a atuação desses oficiais, controle este que deveria se iniciar no momento em que eram providos. O monarca Filipe II (Felipe I de Portugal) era advertido que:

(...) uma das coisas que mais importam ao serviço de Vossa Majestade no Estado da Índia é a acertada eleiçẫo dos capitães e mais oficiais das cidades e fortalezas dele. ${ }^{5}$

\footnotetext{
${ }^{1}$ Agradeço os comentários e sugestôes de Maria João Ferreira, Sandra Pinto, Giuseppina Raggi, Nunziatella Alessandrini, Maria José Ortega Chinchilla e Margarita Rodríguez Garcia. A bibliografia é diversa e faremos referência a ela ao longo do texto, em particular para os tópicos aqui trabalhados.

${ }^{2}$ Por todos: HESPANHA, António Manuel. As vésperas do Leviathan: Instituiçóes e poder político. Portugal século XVII. Lisboa: Almedina, 1986. v. 1.

${ }^{3}$ Já analisada por HESPANHA, António Manuel. História das instituiçôes: Épocas medieval e moderna. Coimbra: Livraria Almedina, 1982.

${ }^{4}$ Sobre a confluência dos interesses da Coroa com seus subordinados ver FURTADO, Júnia Ferreira. Homens de negócio: a interiorização da metrópole e do comércio setecentista. São Paulo: Hucitec, 1999. p. 46-57.

${ }^{5}$ Livro das cidades e fortalezas que a Coroa de Portugal tem nas partes da India e das capitanias e mais cargos que nelas há e da importância deles (c. 1581). Lisboa: Centro de Estudos Históricos Ultramarinos, 1960. p. 3.
} 
O controle sobre os provimentos, porém, nunca foi uniforme, pois o rigor adotado mudava de intensidade em conformidade com a natureza e o estatuto dos ofícios. Estes, por sua vez, não eram definidos somente em função de sua relevância estratégica, difícil de ser determinada em um sistema no qual as hierarquias não eram claras e os poderes eram sobrepostos. Outras variantes determinavam a importância de cada cargo, e consequentemente o rigor de seu provimento, dentre as quais, o estatuto do território onde seria exercido ${ }^{6}$ ou, ainda, a qualidade dos indivíduos que o tinham servido anteriormente. ${ }^{7}$ Essas breves consideraçóes permitem, desde logo, entrever a complexidade que envolve o estudo dos provimentos, como é própria aos temas de investigação relativos à administração "pública" no Antigo Regime.

Para estabelecer uma breve sistematização dos provimentos dos ofícios civis da monarquia portuguesa na Idade Moderna, que é o primeiro passo que aqui nos colocamos (ver tabela ao final do artigo), nossa proposta é diferenciá-los segundo duas modalidades: a concessão precária do ofício, em que se concedia temporariamente o exercício ou a função (por vezes denominada "em serventia") e outra, comumente referida como "em propriedade", cuja concessão era vitalícia e tendencialmente hereditária. ${ }^{8}$

Os marcos cronológicos deste trabalho reportam aos séculos XVII e XVIII, durante os quais os tipos de nomeação se mantiveram praticamente os mesmos. As alteraçóes foram sentidas nos critérios de recrutamento dos servidores assim como nos vocábulos empregues para se referir às formas de provimento. Porém, daremos especial atenção ao século XVIII, para entender particularmente as críticas contundentes à secular prática de patrimonialização dos ofícios que emergiram no período pombalino (1750-1777). 'Tais críticas, embora diversas das que surgiram mais tarde no liberalismo, coincidiam com este na defesa da extinção desta prática considerada pouco compatível com as "luzes" do século XVIII, embora a concessão em propriedade se restringisse a uma tipologia de ofício muito específica, não sendo generalizada a ponto de contribuir para a "privatização dos órgãos públicos". Por fim, ainda que nosso tema seja a administração da monarquia portuguesa, no período mencionado, nosso terreno de eleiçáo será sobretudo a América portuguesa, por ter sido objeto no Setecentos de uma legislação específica no que concerne aos provimentos dos ofícios.

\footnotetext{
${ }^{6}$ CARDIM, Pedro; MIRANDA, Susana. A expansão da Coroa portuguesa e o estatuto político dos territórios. In: FRAGOSO, João; GOUVÊA, Maria de Fátima (Orgs.). Coleçâo o Brasil Colonial: 1580-1720. Rio de Janeiro: Civilização Brasileira, 2014. v. 2, p. 51-106.

${ }^{7}$ Concepção vigente já na Idade Média. BARROS, Henrique Gama. História da Administração pública em Portugal nos séculos XII ao XV. 2. ed. Lisboa: Sá da Costa, 1956. v. 2, p. 232.

${ }^{8} \mathrm{Na}$ monarquia espanhola, para além da tipologia apontada, havia ainda a nomeaçáo de cargos perpétuos transmissíveis ou em juro e herdade. Na monarquia portuguesa, somente alguns cargos mais elevados eram concedidos desta forma, vale dizer, transmissíveis aos filhos apenas com a confirmação régia e, mesmo assim, com muita raridade. A concessão em propriedade, no entanto, pressupunha o regime vitalício e a hereditariedade semiautomática, por necessitar do aval régio, como adiante se verá.

${ }^{9} \mathrm{O}$ termo "patrimonialização" não era utilizado à época. No entanto, pode-se dizer que uma parte dos atores de então tinha uma noção desta realidade, associando a propriedade de ofícios à sua transmissão hereditária.
} 


\section{Os ofícios temporários}

A maioria dos cargos da monarquia portuguesa era nomeada para ser servida por três anos ou por um prazo indefinido, ainda que presuntivamente curto. Decorrido este período, tornavam a ficar vagos e voltavam às mãos do monarca quem, direta ou indiretamente, através de seus tribunais e autoridades no reino e no ultramar, prorrogava o tempo de serviço do antigo titular ou tornava a provê-los em um novo oficial.

Dentre esses ofícios providos temporariamente, os mais importantes cargos da monarquia eram nomeados em Lisboa mediante despacho régio com ou sem consulta dos Conselhos, sendo que poucas vezes foram concedidos através da venda. ${ }^{10}$ Para esses ofícios eram escolhidos os homens mais capacitados (normalmente letrados ou fidalgos), que podiam receber a mercê do cargo gratuitamente ou em troca de serviços prestados. Vice-reis, governadores das armas, governadores de Capitanias, capitães-mores, secretários de governo, ${ }^{11}$ corregedores/ouvidores e juízes de fora são exemplos desses cargos civis que na monarquia portuguesa eram remunerados com um ordenado e que nobilitavam seus ocupantes, ainda que em níveis diversos. Pouquíssimas vezes os beneficiários foram agraciados com a propriedade do cargo, o que se depreende da leitura dos alvarás de nomeação, pois eram escolhidos para ocupar um "lugar" por um prazo relativamente curto e com o objetivo de cumprir uma função muito bem delimitada em seus regimentos.

Os cargos de provedor da Fazenda Real devem ser incluídos nesta lista dos ofícios honoráveis e remunerados, ainda que algumas vezes fossem concedidos em propriedade e até mesmo vendidos pela Coroa. ${ }^{12}$ Há muitos exemplos, sobretudo no ultramar, mas vale citar a compra do ofício de provedor da Fazenda da Capitania do Rio de Janeiro, em 1714, por Francisco do Amaral Gurgel. Segundo o registro da carta emitida pela Chancelaria régia, a propriedade foi adquirida por 40 mil cruzados, montante que serviria para cobrir as des-

\footnotetext{
${ }^{10}$ Como ocorreu com o cargo de secretário do Conselho Ultramarino, comprado por Manoel Lopes da Lavre por 25 mil cruzados. A carta de propriedade foi concedida ao seu filho em 1696. BICALHO, Maria Fernanda. Ascensão e queda dos Lavre. In: MONTEIRO, Rodrigo B.; FEITLER, Bruno; CALAINHO, Daniela; FLORES, Jorge (Orgs.). Raízes do privilégio: Mobilidade social no mundo ibérico do Antigo Regime. Rio de Janeiro: Civilização Brasileira, 2011. p. 300.

${ }^{11} \mathrm{O}$ expectável é que o cargo de secretário de governo fosse provido de forma trienal, porém, na consulta para nomeação deste ofício do Estado do Maranhão, um dos desembargadores do Conselho Ultramarino era favorável "que o sirva por tempo de três anos conforme a natureza deste ofício o que Vossa Majestade poderá estender a vitalício como o é o de Secretário da Bahia e o de Angola”. Arquivo Histórico Ultramarino (AHU)/ Consultas Mistas, códice 21, f. 284v. Sobre o cargo de secretário de governo, ver MELO, Josemar Henrique de. A ideia de arquivo: A secretaria do governo da Capitania de Pernambuco (1687-1809). Tese (Doutorado em Ciências Documentais) - Faculdade de Letras da Universidade do Porto, Porto, 2006.

${ }^{12}$ Para além do exemplo citado, referente ao Rio de Janeiro, foi vendida a propriedade do ofício de provedor da Fazenda da Capitania de Pernambuco em 1675, e de provedor da Fazenda de Angola em 1695. AHU/ Consultas Mistas, códice 51, f. 204; f. 15.
} 
pesas da guerra. ${ }^{13}$ Menos de três anos depois, Bartolomeu de Siqueira Cordovil solicitava a propriedade do mesmo ofício, por nele ter renunciado, com permissão da Coroa, o anterior titular. ${ }^{14}$ Cerca de 17 anos mais tarde, alegando sofrer de achaques, Cordovil pedia a permissão para nomear seu filho como serventuário ${ }^{15}$ e este, após o falecimento do pai em 1741, solicitava uma nova carta de propriedade. ${ }^{16}$

A história merece ser contada porque, apesar de compreender somente 27 anos, dá a exata medida de como se multiplicavam as possibilidades de transmissão de um ofício quando a Coroa o concedia em propriedade. A este tópico se voltará adiante, mas não podemos deixar de observar que apesar de todas as transmissóes da titularidade (renúncias em terceiro sem grau consanguíneo ou por via da hereditariedade) ou mesmo o "transpasse" do serviço/função (arrendamento) necessitarem de consentimento régio, os proprietários tinham espaço de atuação na escolha de seus sucessores ou substitutos, sobretudo em realidades tão afastadas do centro político, como o Rio de Janeiro na primeira metade do século XVIII.

Assim, parece acertado sugerir que, dada a grande probabilidade de os proprietários não servirem por si os seus ofícios, a monarquia portuguesa tenha evitado conceder carta de propriedade dos cargos mais importantes, que deviam ser exercidos por titulares providos em Lisboa, mediante um julgamento mais rigoroso das suas qualidades. $\mathrm{Na}$ verdade, mesmo se os proprietários servissem, esse tipo de provimento não se ajustava à itinerância, por outros cargos e espaços da monarquia, que se defendia para esses altos "funcionários". O enraizamento local e o plausível estabelecimento de redes clientelares dele resultante se reputavam nocivos aos interesses do monarca e do bem comum. ${ }^{17} \mathrm{~A}$ experiência adquirida em muitas paragens ao serviço do monarca era levada em conta na nomeação de ofícios com este estatuto que eram providos, quase sem exceção, em quem tivesse uma condição social à nascença elevada (muitos eram fidalgos destacados). ${ }^{18}$

\footnotetext{
${ }^{13}$ ARQUIVO NACIONAL DA TORRE DO TOMBO (ANTT)/Chancelaria d. João V. Livro 42, f. 108. ${ }^{14}$ Id. Livro 44, f. 321. Nada permite afirmar que tenha se tratado de uma venda entre particulares, porém, sendo esta uma prática ilegal, é natural que náo esteja evidente neste tipo de fonte documental. Sobre o assunto ver: STUMPF, Roberta G. Venalidade de ofícios e honras na América portuguesa: um balanço preliminar. In: ALMEIDA, Suely de; SILVA, Gian Carlo de M.; SILVA, Kalina V.; SOUZA, George F. C. de (Orgs.). Politicas e estratégias administrativas no mundo Atlântico (séc. XV-XVIII). Recife: Universidade Federal de Pernambuco, 2012. p. 145-168.

${ }^{15}$ ANTT/Chancelaria d. João V. Livro 88, f. 313v.

${ }^{16}$ Id. Livro 102, f. 37. Seu filho foi remetido preso para Lisboa em 1770, sem deixar descendência.

${ }^{17}$ Os governadores das conquistas, por exemplo, estavam proibidos de comerciarem (Resoluçáo de 26 de novembro de 1709). Esta proibição estendeu-se a outras importantes autoridades no ultramar mediante a lei de 29 de agosto de 1720. Todas as fontes normativas citadas neste artigo estão disponíveis em: <http://www. iuslusitaniae.fcsh.unl.pt>.

${ }^{18}$ CUNHA, Mafalda Soares da; MONTEIRO, Nuno Gonçalo. Governadores e capitães-mores do império atlântico português nos séculos XVII e XVIII. In: MONTEIRO, Nuno Gonçalo; CARDIM, Pedro; CUNHA, Mafalda Soares da (Orgs.). Optima pars: Elites ibero-americanas do Antigo Regime. Lisboa: Imprensa de Ciências Sociais - ICS, 2005. p. 191-252.
} 
Resultante de uma eleição e nomeação estritamente local, mas obedecendo ainda a um regime de nomeação temporária, os cargos camarários, como vereadores, juízes ordinários e procuradores, não tinham um soldo mensal, mas rendimentos decorrentes das propinas e emolumentos. ${ }^{19}$ Muitas vezes precisavam desempenhar uma atividade rentável, sendo a riqueza, por norma, um dos critérios que devia definir quem eram os principais da terra. A recompensa mais importante em servir à Res publica estava no fato de esses cargos serem honoráveis, ${ }^{20} \mathrm{e}$, ainda que o prestígio que conferiam fosse geograficamente limitado, poderia fazer a diferença nos processos de nobilitação protagonizados no reino. ${ }^{21}$ Da mesma forma, uma vez inserido nas câmaras, era grande a oportunidade de se dar continuidade a uma "carreira" civil ou militar, em escala local, a serviço da monarquia. Mas, diferentemente do sentido atual que atribuímos ao vocábulo, ${ }^{22}$ esta carreira nunca estava vinculada a uma ocupação especializada ou implicava uma ascensão gradual.

Para a questão que aqui nos importa, devemos salientar que, apesar de as eleiçóes trienais das câmaras pressuporem uma rotatividade dos homens a serviço da Res pública, ${ }^{23}$ muitos camaristas monopolizavam tais cargos, em si ou em suas famílias. Aliás, era a própria legislação da monarquia que promovia o monopólio de tais cargos pelas famílias "dos filhos e netos de quem os tinha servido”; mas este é um ponto já muito destacado pela historiografia. ${ }^{24}$ O que queremos salientar é que, embora todos os ofícios de natureza temporária tivessem uma legislação relativamente clara quanto ao período de vigência dos seus exercícios, havia possibilidade legal de prorrogá-los, o que mais uma vez comprova a dificuldade de criar uma tipologia dos provimentos dos ofícios.

Ainda no início do século XIX, o reputado jurista Manuel D’Almeida e Sousa Lobão, na sua tentativa de observar regularidades de provimento, afirmava que tinha visto "o Soberano

${ }^{19}$ Diferenciamos os cargos camarários dos ofícios nomeados pelas Câmaras, que não davam nem tiravam nobreza como, por exemplo, porteiros, guarda-livros, síndicos, solicitadores... No caso dos almotacéis e carcereiros, também eleitos pelos edis, tinham estatutos opostos. O primeiro nobilitava, enquanto o segundo era considerado degradante. ZENHA, Edmundo. Os municípios no Brasil: 1532-1700. São Paulo: Instituto Progresso Editorial, 1948.

${ }^{20}$ Estamos aqui a nos referir sobretudo à nobreza costumeira e não à formalmente sancionada pela monarquia. Sobre o assunto consultar a obra de João Fragoso. FRAGOSO, João. A nobreza vive em bandos: a economia política das melhores famílias da terra do Rio de Janeiro, século XVII. Algumas notas de pesquisa. Tempo. Revista do Departamento de História da UFF, Niterói, v. 8, n. 15, p. 11-35, 2003.

${ }^{21}$ Sobre a notoriedade local como um critério de importância na obtenção de títulos e honras nobilitantes ver: STUMPF, Roberta. Os cavaleiros do ouro e outras estratégias nobilitantes nas Minas Setecentistas. Belo Horizonte: Fino Traço, 2014.

${ }^{22}$ ALFAIA, João. Carreira. In: GOMES, Henrique Martins; FERNANDES, José Pedro Pereira Monteiro. Dicionário jurídico da administração pública. Coimbra: Atlântida, 1972. v. II, p. 222-223.

${ }^{23}$ Em teoria, os eleitos para servirem os cargos de República só podiam reincidir no cargo após três anos. Apud MAGALHÃES, Joaquim Romero. Reflexôes sobre a estrutura municipal portuguesa e a sociedade colonial brasileira. In: . Concelhos e organização municipal na época moderna. Coimbra: Miunças 1, 2011. p. 128.

${ }^{24}$ Por exemplo: SOUSA, Avanete Pereira. A Bahia no século XVIII: Poder político local e actividades económicas. São Paulo: Alameda, 2012. p. 89. 
dando ofícios, que as câmaras costumavam eleger", pelo que, concluía, "nada certo posso aqui (a)firmar". ${ }^{25}$ As dúvidas deste contemporâneo nos incentivam a fazer uma breve pausa, antes de retornar aos padróes de provimento que estamos procurando delimitar em conformidade com os estatutos dos ofícios. Na falta de indicação precisa, arriscamos a dizer que, com muita probabilidade, esses ofícios que ele "viu" o soberano dar eram o de escrivão da câmara e o de escrivão dos órfãos. Originalmente eleitos pelas câmaras, com muita frequência foram providos em propriedade e, portanto, pelo centro político. Há evidências, ainda, de que tenham-se constituído em uma fonte de arrecadaçáo para a monarquia portuguesa, sobretudo no século XVIII, ${ }^{26}$ quando foram vendidos de forma largamente difundida, sobretudo na América portuguesa.

No que se refere ao cargo de escrivão de órfăos da Capitania do Rio de Janeiro, a possibilidade de reconstituir o nome de todos os seus titulares/servidores ao longo de quase 230 anos (1570-1797) confirmou empiricamente como um ofício (no caso intermédio) podia estar sujeito a várias modalidades de provimento e transmissáo. Neste longo período, a maior recorrência foram as concessóes em propriedade e a consequente patrimonialização, ou seja, a transmissão aos filhos. Outra regularidade é o fato de os proprietários não exercerem o cargo, o que significa que os serventuários acabaram por imperar. Com a eventual vacância do ofício (normalmente por morte do proprietário), a experiência adquirida pelos serventuários os favorecia na obtenção da titularidade, uma dinâmica que se manteve até 1742 quando o cargo passou a ser provido em serventia trienal, mediante donativo, no início pela Coroa e, depois, pela Junta da Fazenda da Capitania. ${ }^{27}$

De qualquer forma, esta é uma tipologia de concessôes que se ajusta aos ofícios intermédios, como adiante se verá. Retomando aos ofícios mais importantes da monarquia e aos camarários (vereadores, juízes ordinários e procuradores) seus regimes de provimento se mantiveram inalterados ao longo do período aqui analisado. Ao menos é o que se pode dizer sobre a preservação das instituiçóes e autoridades encarregadas de os proverem/elegerem, ou ainda sobre o fato de manterem seu caráter temporário. Também os trâmites burocráticos que envolviam o processo de escolha/eleição até a tomada de posse/juramento não se alteraram substancialmente, seja no reino ou na América portuguesa.

No entanto, os critérios de escolha e nomeação para os principais cargos da monarquia foram menos dados a alteraçóes (a fidalguia, a experiência e as letras) do que àqueles que

\footnotetext{
${ }^{25}$ LOBÃO, Manuel D’Almeida e Sousa. Notas de uso prático e críticas, adiçôes, ilustraçôes e remissôes sobre todos os títulos e todos os SS do Livro $2^{\circ}$ das Instituiçóes de direito civil lusitano do d. Pascoal José de Melo e Freire. Lisboa: Imprensa Nacional, 1836. parte II, p. 26-27.

${ }^{26}$ Para tanto ver: ANTT/Chancelaria de d. João V e Chancelaria de d. José I (relativos ao período de 1706-1777).

${ }^{27}$ STUMPF, Roberta. "Qualidades formais, requisitos efetivos: a imagem do bom servidor régio no Império português do século XVIII”. Comunicação apresentada no IV Encontro internacional de História Colonial, Belém do Pará, 2012 (inédito). MACEDO, Deoclécio Leite de. Tabeliães do Rio de Janeiro, $1^{o}$ ao $4^{\circ}$ ofício de Notas, Rio de Janeiro: Arquivo Nacional, 2007.
} 
eram utilizados na eleição dos cargos camarários, que nunca foram uniformes ou estanques. Pelo contrário, as leis em todo território português foram suficientemente imprecisas na definição das qualidades necessárias para se ingressar nas câmaras. ${ }^{28}$ Porém, em se tratando de cargos que davam nobreza (oficial ou costumeira, de acordo com a qualidade da terra), o fato de os requisitos de ingresso variarem não significou que não fossem exigentes. Mesmo assim, voltamos a frisar, nunca os cargos camarários foram patrimonializados, como aconteceu frequentemente na monarquia hispânica, na península e no ultramar, mediante a venda pela Coroa, promovida sobretudo no século XVII. ${ }^{29}$

\section{Ofícios intermédios: provimento em propriedade}

Tendo percorrido dois planos da administração da monarquia portuguesa, chegamos finalmente ao terceiro, composto pelos ofícios intermédios, como escrivães, tabeliães, ${ }^{30}$ juízes dos órfāos, meirinhos, entre outros, que eram remunerados, não honoráveis, ainda que não incompatíveis com a nobreza. Numerosos e estratégicos à administraçấo da monarquia portuguesa, tanto no reino como no império, nem por isso foram considerados pelos seus coetâneos e pela historiografia. Mas é sobre estes que aqui nos deteremos, não só pelo velho e legítimo argumento de que é preciso preencher lacunas historiográficas, mas sobretudo porque foram estes, apesar de sua natureza "trienal", que maiormente foram dados em propriedade.

Esta modalidade de provimento era de exclusividade do monarca, o que significa que somente no reino é que se expediam as cartas de propriedade. Provavelmente a defesa ou até predileção por esta forma de nomeação dos ofícios intermédios pode ser explicada em função desse apanágio régio, por essa dinâmica de provimento permitir um controle mais centralizado da "máquina" administrativa. Mas antes de avançarmos com as hipóteses que nos levariam, inevitavelmente, às críticas "pombalinas" acerca da patrimonialização dos ofícios, seria importante entender a lógica que estava subjacente a esta defesa que imperou até este período.

De acordo com a cultura política do Antigo Regime, de origem medieval, era uma questão de justiça o monarca expressar gratidáo concedendo mercês como cargos e honras

\footnotetext{
${ }^{28}$ MAGALHÁES, Joaquim Romero. Os nobres da governança da terra. In: Optima pars. op. cit., p. 65-71. MONTEIRO, Nuno Gonçalo. Elites locais e mobilidade social em Portugal nos finais do Antigo Regime. Análise social, Lisboa, ICS, n. 147, p. 335-368, 1997.

${ }^{29}$ HERMÁNEZ BENÍTEZ, Mauro. Venalidad de oficios municipales en la Castilla del siglo XVIII: un ensayo de cuantificacions. Chronica Nova, n. 33, p. 95-129, 2007. Destacamos, ainda, os trabalhos de María López Díaz e Pilar Ponce Leiva. In: ANDÚJAR CASTILLO, Francisco; FELICES DE LA FUENTE, Maria del Mar (Eds.). El poder del dinero: Ventas de cargos y honores en el Antiguo Régimen. Madri: Biblioteca Nueva, 2011.

${ }^{30}$ Nas Ordenaçôes Afonsinas, Manuelinas e Filipinas todos os títulos sobre renúncias, arrendamento e venda de propriedade de ofícios referem-se aos ofícios de tabeliães e escrivães.
} 
aos súbditos que se destacavam nos serviços prestados. ${ }^{31}$ Sem dúvida que, não havendo um número suficiente de cargos mais importantes da monarquia para retribuir a tantos beneméritos, ao se conceder um cargo intermédio em propriedade, em vez de dá-lo em serventia (normalmente trienal), estava-se a se retribuir os serviços de forma mais honrosa e valiosa, inclusive pecuniariamente. ${ }^{32}$

Muitas críticas a este sistema de doação em propriedade apontavam para a incongruência em se dar um bem da Coroa de forma a torná-lo indisponível, por um período supostamente indeterminado, para futuras concessões régias. ${ }^{33}$ Afinal, as propriedades dos ofícios não vagavam necessariamente com a morte do titular (diferentemente dos ofícios vitalícios), pois o herdeiro privilegiado, segundo o direito consuetudinário, poderia requerer a carta e se tornar o novo proprietário. $\mathrm{O}$ que acontecia com frequência e, quase sempre, com êxito.

Mesmo assim, a patrimonialização dos ofícios foi defendida por quem entendia ser esta uma forma eficaz de garantir o bom e regular funcionamento da administração, com os interesses do rei conjugados aos dos titulares. Aos olhos de hoje, é difícil reconhecer a validade desta posição entusiasta quando sabemos que os ofícios "privatizados" podiam vir a se tornar bens transacionáveis, ${ }^{34}$ muitas vezes em benefício exclusivo dos particulares.

Porém, mais importante do que desconstruir visões anacrônicas é saber qual era o impacto quantitativo desses provimentos, bem como averiguar se a nomeação desses proprietários implicava um processo mais rigoroso na avaliação de suas qualidades, o que teoricamente deveria acontecer, sobretudo por decorrer no centro político da monarquia. Também nos casos em que se solicitava a transmissão da propriedade do ofício em terceiro (com ou sem grau consanguíneo) os pareceres dos tribunais só eram despachados após a análise de documentos produzidos por outras autoridades régias encarregadas de investigar a qualidade dos "novos" servidores, assim como a legalidade desta operação (renúncia). É certo que nem sempre as exigências legais e morais eram respeitadas, pois o favoritismo e a venalidade podiam comprometer o rigor e o controle requeridos nas nomeaçóes dos proprietários.

De qualquer forma, acreditava-se que as qualidades dos titulares/proprietários eram superiores aos dos súditos nomeados para servir temporariamente, mas as vantagens atribuídas

\footnotetext{
${ }^{31}$ OLIVAL, Fernanda. As ordens militares e o Estado moderno: Honra, mercê e venalidade (1641-1789). Lisboa: Estar, 2001.

${ }^{32} \mathrm{O}$ termo "em propriedade" será largamente difundido no século XVIII, mas já aparece com frequência no Seiscentos. No século XVI, como se pode verificar no documento já citado, produzido por volta de 1580, provia-se "temporalmente" ou "em vida". Livro das cidades e fortalezas..., op. cit. Sobre o termo "em propriedade", ver nota 9.

${ }^{33}$ Sobre os ofícios serem ou não bens da Coroa, abordaremos adiante.

${ }^{34}$ HESPANHA, António Manuel. Poder e instituiçóes na Europa do Antigo Regime: coletânea de textos. Lisboa: Fundação Calouste Gulbenkian, 1984. p. 36. . História das instituiçôes..., op. cit., p. 310ss. Sobre o tema, ver STUMPF, Roberta. Formas de venalidade de ofícios na monarquia portuguesa do século XVIII. In:___ CHATURVEDULA, Nandini (Orgs.). Cargos e ofícios nas monarquias ibéricas (séculos XVII e XVIII): provimento, controlo e venalidade. Lisboa: Centro de História de Além-Mar da Universidade de Lisboa, 2012. p. 279-298.
} 
àquela forma de provimento não se esgotavam aí. Aqueles que eram providos em propriedade, para além dos benefícios econômicos, gozavam do prestígio resultante de ter obtido uma carta de propriedade de um ofício que, mesmo sendo de estatuto inferior, como escrivão ou tabelião, havia sido concedida por órgãos régios, sendo comum, portanto, que o título de proprietário fosse ostentado publicamente. Desta forma, e seguindo a própria lógica da cultura política do Antigo Regime, na qual receber uma mercê implicava gratidão, deste titular era ainda mais esperado que cumprisse fielmente os deveres que lhe eram atribuídos ao seu ofício.

Essa mesma linha de raciocínio, que associava os provimentos de ofício em propriedade à eficácia da administração, alimentou muitos discursos que surpreendem pelo viés pragmático que, no entanto, não se aproxima à racionalidade administrativa legal que supostamente emergiu na segunda metade do século XVIII. A vantagem que acarretaria na continuidade da administração, com o estabelecimento de uma tradição familiar do serviço "público", é um dos exemplos que podem ser assinalados, ${ }^{35}$ como se pode ver no caso seguinte, no qual se observa com tanta clareza esta "cultura administrativa".

Em 1740, Gaspar Pereira de Sampaio, escrivão há 35 anos da câmara da Vila de Pinhel, província da Beira, solicitava a Sua Majestade que seu filho mais velho e natural sucessor ${ }^{36}$ servisse seu ofício temporariamente. Alegava, como era comum, sofrer de "achaques" mas, por informação do corregedor da mesma Vila, viemos a saber que acumulava o ofício de juiz dos órfâos daquela localidade, durante o mesmo período. ${ }^{37}$ Tais circunstâncias já seriam suficientes para que obtivesse a graça requerida, mas Sampaio lembrava ainda que, se fosse atendido, evitaria:

(...) por este modo o descaminho que costuma haver nos papéis com mudanças de cartórios por serventuários estranhos, como já sucedeu no dito suplicante em que faltam papéis importantes ao serviço de Vossa Majestade do tempo em que ele o não servia.

O procurador da Coroa não hesitou em dar parecer favorável. Mas a Mesa do Desembargo do Paço expressou sua discordância invocando um argumento estruturante, recorrente nas leis e nas consultas dos tribunais: os proprietários devem servir por si (e sozinho) os seus ofícios. ${ }^{38}$ Assim,

(...) podia seguir grande prejuízo à boa administração da justiça servindo o pai um dia e o filho em outro, e somente quando o pai tem legítimo impedimento, e o filho é capaz, se concede a este provimento enquanto dura o impedimento de seu pai.

\footnotetext{
${ }^{35}$ HESPANHA, António Manuel. História das instituiçóes..., op. cit., p. 393.

${ }^{36}$ ANTT/Desembargo do Paço. Repartição de justiça e despacho da Mesa. Maço 1.075, consultas 1.742.

${ }^{37}$ ANTT/Registo Geral de Mercês, Mercês de d. Pedro II. Livro 14, f. 205 (1.701). Carta. Juiz dos Órfáos na vila de Pinhel.

${ }^{38}$ Tema já abordado em STUMPF, Roberta. Formas de venalidade..., op. cit.
} 
Porém, o desembargador José Vaz de Carvalho, cujo voto acabou por ser acatado no parecer final, recorreu mais uma vez à eficiência administrativa, mas agora para defender um argumento muito pouco recorrente, pois:

(...) é mui conveniente que os filhos que hão de suceder nos ofícios de seus pais os exercitem em sua vida e com a doutrina dos mesmos pais se façam neles práticos, sem passarem a pessoas estranhas que como não tem conveniência na sua conservação, regularmente os (d)estroem e perdem. ${ }^{39}$

O exemplo é emblemático e ilustra muito bem a ideia de que um ofício ao ser concedido em propriedade, com sua hereditariedade potencial, favorecia à preservação da memória e da prática administrativas. No caso do argumento defendido pelo suplicante e pelo desembargador Carvalho, é possível estabelecer uma analogia com os ofícios mecânicos, cuja aprendizagem se fazia nas corporações de ofícios entre mestre e aprendizes, com a diferença de que os escrivães, ou outros cargos intermédios, não eram desqualificantes, pois não davam nem tiravam nobreza.

O caso em questão, a lembrança recorrente à eficácia da administração justificava posicionamentos diversos, mas todos os pareceres insistiam em um mesmo ponto: os súbditos escolhidos para os cargos é quem deveriam servi-los. Mas Gaspar Sampaio, não podendo servir, enfatizava a inconveniência de se nomear "serventuário estranho", pelo que argumentava a favor da concessão da serventia a seu primogênito, quem afinal tinha grande possibilidade de ganhar a propriedade quando de sua morte. No limite, seu filho acabava por figurar nesta súplica como um "proprietário por antecipação", o que evitava a rotatividade de oficiais em um mesmo cargo, prática que desagradava a monarquia. No decreto de 16 de maio de 1650 vemos como se aconselha que "sempre que o proprietário não puder servir, eleja o mesmo serventuário, e assim este fica como um proprietário alternativo". ${ }^{40}$ Semelhante raciocínio expressou a Mesa do Desembargo do Paço, em 1718, ao defender sem votos em contrário que era "mais útil fazer renúncia em pessoa que pode (pudesse) servir", o ofício de escrivão dos órfăos do Concelho de Besteiros, comarca de Viseu, do que "exercitasse o ofício por mãos de serventuário". ${ }^{41} \mathrm{O}$ titular estava "legitimamente impedido", mas o parecer recomendava a substituição de um proprietário por outro, evitando, desta forma, a alternância sucessiva.

\footnotetext{
${ }^{39}$ ANTT/Desembargo do Paço - Repartição de justiça e despacho da Mesa. Maço 1.075, consultas 1.742. 40 "Serventuários uma vez nomeados fiquem certos para servirem em qualquer outro impedimento dos proprietários" (grifos nossos). A categoria "proprietário alternativo” era juridicamente inexistente.

${ }^{41}$ Como queria o titular Manuel de Freitas Ferreira. ANTT/Desembargo do Paço. Maço 1.002, doc. 52.
} 


\section{A transmissão hereditária dos ofícios}

Protagonistas frequentes nesta documentação administrativa, as viúvas dos proprietários de ofícios entravam com requerimentos de diversas ordens para defender aqueles que podemos considerar como sendo os direitos que a elas cabiam representar, na ausência do paterfamilias. Foi este o caso de Antônia Rosada, viúva de Francisco Gomes de Gouveia e tutora de um filho menor (de 25 anos). Em 1700, solicitou autorizaçáo para nomear um novo serventuário para o ofício de escrivão da Alfândega e Almoxarifado do Rio de Janeiro, pois o atual, que servia há nove anos,

(...) não mais contribuía (do) que com uma porção limitada a respeito do rendimento do dito ofício com que se não podia sustentar por ter grande família, e se achar com empenhos e dívida por causa da morte do dito marido. ${ }^{42}$

Alegaçôes similares, relacionadas com a pobreza extrema ou a dificuldade material para manter a honra familiar (como dar estado de casada ou religiosa às filhas), levavam os tribunais régios, como já vimos em outros trabalhos, a autorizar a alienação (venda) do ofício. ${ }^{43}$ Mas este não era o caso de Rozada, que queria garantir a titularidade em seu filho, embora, por questôes desconhecidas, saibamos apenas que, em 1716, foi sua filha quem solicitou a propriedade do ofício para quem com ela se casasse. ${ }^{44}$

Casos como este ilustram como era resguardado o direito dos "herdeiros" sempre que foi preciso decidir oficialmente o futuro dos ofícios concedidos em propriedade, sobretudo no caso da alienação em terceiros sem grau consanguíneo, porque contrariava a "expectativas dos filhos". ${ }^{45} \mathrm{Em} \mathrm{1705}$, ordenou-se, por exemplo, que "não consultassem requerimentos de renúncias de ofícios, ou fazenda, não sendo nos filhos dos mesmos proprietários, salvo havendo causa muito justa"46 e nessa mesma linha de raciocínio é que se pode entender a proibição legal da venda de ofícios entre particulares. Tal como mostrou António Hespanha, se no direito comum os filhos náo tinham seus direitos reconhecidos "no plano do direito

\footnotetext{
${ }^{42}$ ANTT/Chancelaria d. João V. Livro 33, f. 347v. AHU/Rio de Janeiro, cx. 7, doc. 1; cx. 6, doc. 136. Também aqui a preocupação em não contrariar os direitos dos serventuários está explícita. A suplicante alegava que este em questão "não tinha perda em largar o dito ofício por ter outro que pode servir na mesma Alfândega de escrivão da abertura, que é de seu filho...”.

${ }^{43}$ STUMPF, Roberta. Formas de venalidade... op. cit. Há uma extensa legislação sobre o assunto, já referida e analisada por HESPANHA, António Manuel. As vésperas do Leviathan. op. cit., p. 722.

${ }^{44}$ ANTT/Chancelaria de d. João V. Livro 8, f. 403v.

${ }^{45}$ HESPANHA, António Manuel, História das instituiçôes..., op. cit., p. 327-9. Embora os ofícios não fossem discriminados no direito sucessório, expresso nas Ordenaçóes, quando foram concedidos pelo monarca por direito consuetudinário aos filhos dos anteriores proprietários, as normas de sucessão que vigoraram foram as correntes, tal como a primogenitura.

${ }^{46}$ Decreto de 27 de outubro de 1705.
} 
pátrio, entendia-se que o príncipe estava obrigado a dar aos filhos os ofícios dos pais, desde que estes tivessem bem servido". ${ }^{47}$ Em síntese, e segundo nossa interpretação, não sendo os ofícios bens patrimoniais (livres ou vinculados), no caso da morte do último proprietário era esperado que o monarca desse o ofício ao herdeiro privilegiado, independentemente da propriedade ter sido anteriormente concedida em gratuidade, em remuneração de serviço ou mesmo por compra.

O estatuto jurídico do proprietário, portanto, era equivalente ao do usufrutuário vitalício, pois não podia dispor do ofício como entendesse, uma vez que detinha apenas seu domínio, usufruindo de suas rendas e privilégios. ${ }^{48} \mathrm{O}$ que aqui se retoma, mais uma vez, é o debate sobre os ofícios serem ou náo bens da Coroa, referido ainda em 1805 pelo jurista Manuel D’Almeida e Sousa Lobão, que assim se posiciona vivamente:

(...) que ainda que tais ofícios se conumeram entre bens de raiz para Moraes liv. 6 cap. 1 n. 33, o domínio deles é do soberano, e o oficial só tem a simples administração. ${ }^{49}$

Nas cartas de propriedade dos ofícios intermédios emitidas pela chancelaria régia no século XVIII, para citar mais um exemplo, há sempre uma expressa referência à desobrigaçáo de:

(...) havendo eu (o rei) por meu serviço em algum tempo tirar ou extinguir o dito ofício por qualquer causa que seja lhe não ficará por isso minha fazenda obrigada a satisfação alguma.. ${ }^{50}$

Ainda que não houvesse consenso sobre a matéria, a verdade é que os ofícios concedidos em propriedade não aparecem na documentação como se tratassem de um bem particular. Não constam, por exemplo, nos inventários, ${ }^{51}$ junto à prataria, às cômodas, aos oratórios, às casas e às quintas. Quando naquele "que se fez por morte de Valentim de Oliveira", em 1664, último proprietário do ofício de escrivão do Juízo do Cível de Lisboa, ${ }^{52}$ nos surpreende que este aparecesse na lista dos seus bens de raiz. Contudo, ao final do documento nos esclarece o juiz:

\footnotetext{
${ }^{47}$ HESPANHA, António Manuel. História das instituiçôes..., op. cit., p. 327-8.

${ }^{48}$ Porém, é necessário frisar que esta noção não era consensual entre os juristas, como nos alerta o historiador António Manuel Hespanha nas suas obras aqui referidas.

${ }^{49}$ LOBÃO, Manuel D’Almeida e Sousa. Notas de uso prático e críticas. op. cit, parte II, p. 412. Um debate acalorado se pode acompanhar em: OFÍCIO de justiça e Fazenda pode tirar El-rei sem ser obrigado a satisfação. In: Repertório das Ordenaçôes, e Leis do Reino de Portugal. 1795. Tomo III, Letras J-PA, p. 816-818.

${ }^{50}$ ANTT/Chancelaria Régia d. João V. Livro 52, f. 12.

${ }^{51}$ Nos inventários, os ofícios são referidos sobretudo quando implicam um valor transaccional. Quando foram comprados ou vendidos e as dívidas não haviam sido quitadas, por exemplo.

${ }^{52}$ Este documento é tanto mais interessante por constar que o ofício em causa foi havido "por mercê de Sua Majestade" mediante o donativo de 3.000 cruzados, mas com a obrigação de pagar 36.000 reis cada ano à mulher do último proprietário. Neste caso, vemos a Coroa intermediar a venda de um ofício entre dois particulares.
} 
(...) que não é de partilha e mandou que não viesse nela posto que saísse do dote da viúva assim por não serem partíveis os ofícios nem a estimação deles por serem da mercê e data do príncipe que as pode tirar e extinguir sem que sua real fazenda fique obrigada a satisfação alguma. ${ }^{53}$

A noção de propriedade de ofício, em última instância, estava muito distante do conceito atual de propriedade consagrado apenas com o Código Civil (napoleônico) de 1804, ${ }^{54}$ apesar do questionamento dos historicistas no século XIX. ${ }^{55}$ Desde então, triunfa a ideia de que esta é individual, privada, plena, perfeita e não compartida, mas no Antigo Regime esta visão não imperava, sobretudo para os ofícios.

Porém, como vimos até agora, se os proprietários não tinham formalmente o direito de deixar os ofícios aos seus filhos, tinham muitos outros. Podiam, por exemplo, nomear em terceiro o usufruto dos mesmos (arrendar), à semelhança do que faziam os senhorios das terras quando as concediam em enfiteuse (em vida ou vidas), analogia que se torna ainda mais plausível se lembrarmos que, em ambos os casos, em troca da concessão do uso, o enfiteuta era obrigado a pagar parcela do rendimento da concessão recebida (ofício/terra). Esses titulares dos ofícios podiam ainda renunciar (alienar) e muitas vezes lhes era concedido o direito de arrematar (vender) ou até mesmo penhorar os rendimentos ou o próprio ofício para pagamento de dívidas. Evidentemente que esses direitos dependiam do consentimento régio e eram, em teoria, analisados caso a caso. ${ }^{56}$ Mas, de qualquer forma, demonstram como os ofícios, não sendo bens patrimoniais, podiam ser transacionados, gerando renda a seus proprietários.

As fontes normativas, no entanto, sugerem um grau de interferência do poder régio nessas transmissóes e transações que a prática administrativa nem sempre reforça, ainda que seja necessário matizar com a devida atenção o grau de autonomia que detinham os titulares. Esta é uma questão importantíssima a se levar em conta na compreensão da administração no Antigo Regime português, pois, ao fim e ao cabo, pode ser tomada como um dos traços que mais contrastam com a administração burocrática, baseada em critérios racionais, tal como defendiam os liberais. Mas, como já dissemos, antes mesmo do liberalismo, no reinado de d. José, uma dessas manifestaçóes de autonomia dos titulares foi questionada. Referimos à transmissão semiautomática dos ofícios aos primogênitos, fortemente combatida no Regimento com força de lei de 23 de novembro de $1770:{ }^{57}$

\footnotetext{
${ }^{53}$ ANTT/Inventários Orfanológicos. Letra V, maço 16, n. 6. Agradeço a Andreia Durães por ter-me disponibilizado esta fonte documental.

${ }^{54}$ GROSSI, Paolo. Historia del derecho de propiedad: La irrupción del colectivismo en la conciencia europea. Barcelona: Ariel, 1986.

${ }^{55}$ GROSSI, Paolo. Assolutismo giuridico e diritto privato. Milão: Giuffre, 1998. p. 126-140.

${ }^{56}$ A execução dos rendimentos do ofício era expressamente proibida sem licença. Alvará de 26 de junho 1689.

${ }^{57}$ Regimento com força de lei, de 23 de novembro de 1770. "Pelo qual se prescreve como errôneo o abuso do direito chamado consuetudinário, e se dão as providências necessárias para o provimento, e serventia dos ofícios”.
} 
(...) a diametral contradição, em que o direito (consuetudinário) se acha com as Leis, e costumes de todas as naçōes polidas da Europa e na essencial repugnância que contém o passarem aos filhos e sucessores inábeis os ofícios que de sua natureza requerem indústria própria e pessoal daqueles que os devem servir, não para o seu particular interesse mas para a utilidade pública que fizera necessária a criação deles.

O questionamento do princípio da hereditariedade como força motriz dos provimentos dos ofícios mais uma vez esbarra na ideia de que a primazia devia ser dada à "qualidade/ capacidade" dos funcionários, já presente no decreto de $1754^{58}$ e, sobretudo, na lei de $1761 .^{59}$ Em ambos os casos a oposição à patrimonialização está fundamentada nesta perspectiva favorável à "racionalidade" administrativa que teria se iniciado na segunda metade do século XVIII. Porém, outros motivos igualmente relevantes merecem ser lembrados para explicar esta oposição à transmissão "sucessória" dos ofícios como o aumento do número daqueles que, com a morte do proprietário, ficariam vagos e, ao serem revertidos para as mãos do monarca, alimentariam o sistema de remuneração de serviços.

Assim, será possível afirmar que, a partir da segunda metade do século XVIII, esse questionamento da sucessão hereditária dos ofícios, legitimada pelo direito consuetudinário, objetivava também a redução do provimento dos ofícios intermédios em propriedade? É exatamente isto que as fontes consultadas nos permitem defender, só que com uma correçẫo: foi no reinado de d. João V (1706-1750) que as diretrizes que apontam para uma mudança na política de nomeação dos ofícios começam a se fazer sentir. Não há na primeira metade desta centúria uma produçáo normativa que dê continuidade à defesa da modalidade de provimento em propriedade. Do teor de algumas leis extraordinárias se deduz que a concessão temporária dos ofícios intermédios passou a ser vista como vantajosa, sobretudo por questôes financeiras.

Importantes referências são o decreto de 18 de maio de 1722, que obrigava os oficiais das novas serventias de cargos intermédios a pagar à Coroa a terça parte do rendimento anual dos seus ofícios (à maneira do que faziam os proprietários com seus serventuários), assim como o decreto de 18 de fevereiro de 1741 que incentivou a venda dessas serventias

\footnotetext{
${ }^{58}$ No decreto de 20 de abril de 1754 se proibia “todas as renúncias de ofícios”, mesmo aquelas que normalmente eram consentidas "por título de dote, religião, pagamento de credores em falta de outros bens, ou por qualquer outra causa pia”. Este decreto reflete também a tentativa de se controlar a prática da venda de ofícios entre particulares, proibida mas escamoteada sob a prática da renúncia. Sobre o tema ver o brevíssimo, mas pioneiro, artigo de SILVA, Francisco Ribeiro da. Venalidade e hereditariedade dos ofícios públicos em Portugal nos séculos XVI e XVII. Alguns aspectos. In: Separata da Revista do Centro de História da Universidade do Porto, v. 8, p. 203-213, 1988.

59 Já na lei de 1761, o princípio da hereditariedade fora questionado pois não impedia que os ofícios acabassem em pessoas "impróprias e abjectas". GALLO, Alberto. La venalidad de oficios públicos durante el siglo XVIII. In: BELLINGERI, Marco (Coord.). Dinámicas de Antiguo Régimen y orden constitucional: Representación, justicia y administración. Siglos XVIII-XIX. Turim: Otto, 2000. p. 165.
} 
para os ofícios americanos. ${ }^{60}$ Mas isto é o que nos dizem as leis, e um confronto com fontes documentais de outra natureza pode nos ajudar a entender melhor quais foram as mudanças propostas e efetivadas no século XVIII.

\section{O século XVIII: mudanças e continuidades nos provimentos dos ofícios intermédios}

Em 1724, o então governador do Rio de Janeiro, Luiz Vahia Monteiro, foi solicitado a informar sobre os ofícios que naquela Capitania não tinham proprietários, ou seja, que poderiam em breve "se fazer receita da terça parte dos ditos rendimentos" ${ }^{61} \mathrm{Na}$ lista do governador constam somente oito cargos de diferentes órgãos de justiça, fazenda e administração local: um número absolutamente irrisório, mesmo que não saibamos com precisão quantos eram os ofícios intermédios naquela Capitania. É bem possível que o governador, preocupado com a implantação de uma medida fiscal que poderia desinteressar os súditos do serviço nos ofícios desta natureza, tenha alterado os números. Mas, se assim procedeu é porque náo era descabido acreditar que muitos dos ofícios intermédios no Rio de Janeiro, a futura capital da América portuguesa, estivessem sido concedidos em propriedade no início do século XVIII.

Todavia, esta tendência foi se revertendo no decorrer do reinado joanino. Tendo em mente que as propriedades de ofício só podiam ser concedidas no centro político, em Lisboa, é significativo observar que dentre todos os provimentos de ofícios intermédios civis para o território que compreende a Comarca do Rio de Janeiro, registrados na chancelaria régia neste período (1706-1750), apenas 39\% foram dados em propriedade, sobretudo pela via da hereditariedade e nunca em troca de serviços prestados. ${ }^{62}$ Tal porcentagem se reduz significativamente na década de 1740 , já que, conforme referido, se promoveu a venda da serventia dos ofícios americanos.

No período pombalino, as mudanças foram também graduais. Em 1758, após essas vendas efetivadas no Reino terem estimulado um mercado entre particulares, decretou-se em 20 de abril a venda de propriedades na América com o auxílio de dois conselheiros do Conselho Ultramarino enviados ao Brasil. ${ }^{63}$ Com o retorno dos mesmos ao Reino em 1767, após o fracasso da "missão", os ofícios voltaram a ser vendidos em regime temporário

${ }^{60}$ AVELLAR, Hélio de Alcântara. História administrativa do Brasil: a administração pombalina. Brasília: FUNCEP/UnB, 1983. p. 290-91.

${ }^{61}$ A referência a este documento nos foi concedida pela Profa. Maria Fernanda Bicalho, a quem mais uma vez agradeço. AHU/Rio de Janeiro. Catalogados Castro e Almeida, doc. 4718 (1724).

${ }^{62}$ Os demais: $41 \%$ em serventia e $10 \%$ sem especificação. ANTT/Chancelaria Régia, d. João V. A Comarca do Rio de Janeiro era um território imenso que compreendia, no Setecentos, as Capitanias do Rio de Janeiro, Espírito Santo, Santa Catarina e Rio Grande de São Pedro.

${ }^{63}$ Alvará de 20 de abril de 1758: "Para se arrematarem os ofícios de justiça e fazenda do Brasil". 
(normalmente em serventias trienais, e sempre com a faculdade para se renunciar ao serviço em caso de impedimento). No reinado josefino, os provimentos (por mérito ou compra) passaram cada vez mais a ser efetuados na América, tendo sido este provavelmente um dos motivos para que se criassem as Juntas de Fazenda em cada uma das Capitanias a partir de 1761. Presididas pelo governador, proviam os ofícios fazendários, mas não em propriedade, já que este regime de provimento continuou a ser exclusivo das instituiçôes reinóis. ${ }^{64}$ $\mathrm{Na}$ chancelaria régia, no entanto, o registro das concessóes de ofícios nessa modalidade torna-se cada vez mais escasso, e mesmo assim apenas para eventuais casos "sucessórios". ${ }^{65}$

Um bom exemplo dessa predominância paulatina dos provimentos dos ofícios em regime temporário são as listas de ofícios das Capitanias que pertenciam à Comarca do Rio de Janeiro produzidas pelo vice-rei do Estado do Brasil, Luís de Vasconcelos e Sousa, em 1786, em resposta à solicitação do ministro Martinho de Melo e Castro. ${ }^{66}$ Se tomarmos apenas os da capital, a cidade do Rio de Janeiro, encontramos 137 ofícios intermédios (prioritários nesta listagem), discriminados segundo quatro modalidades de provimento: serventia ou propriedade (com donativo ou sem donativo). Dentre estes, $86 \%$ estavam sendo exercidos de forma trienal e poucos haviam sido adquiridos mediante a venda. Quando tratou de responder ao ministro sobre qual seria a melhor forma de provimento desses ofícios, o vice-rei foi categórico:

(...) há muito tempo estou inteiramente persuadido que o mais conveniente ao Serviço de Sua Majestade e ao Público é que todos eles se deem sem rematação nem donativo, mas por serventias anuais como se pratica nos que são providos pela Junta da Real Fazenda pelo ViceRei, nos quais provimentos precede a informação da idoneidade do sujeito e como são anuais, quando suceda que algum náo cumpra as suas obrigaçóes, no fim de cada ano se lhe pode negar o provimento. ${ }^{67}$

Não consta que tal tipologia de provimento (anual) tenha sido aplicada na generalidade, apesar de contar com outros defensores de renome como o posterior vice-rei do Brasil, d. Fernando José de Portugal, futuro marquês de Aguiar. ${ }^{68}$ Mas o que se pretende enfatizar é a

\footnotetext{
${ }^{64} \mathrm{E}$ assim sempre fora, até a mudança da Corte ao Brasil. No decreto de 20 de outubro de 1798, se declarava que às Juntas da Fazenda dos Domínios Ultramarinos pertenciam as nomeaçôes de serventuários de todos os ofícios de fazenda, ficando reservadas as propriedades e as serventias vitalícias para delas fazer mercê por Decreto, ou em Resolução de Consultas dos Tribunais. AHU/Consultas mistas. Códice 28.

${ }^{65}$ ANTT/Chancelaria Régia, d. José I.

${ }^{66}$ Correspondência com a corte. Desde 1o de janeiro de 1782 até 20 de dezembro do mesmo ano. Biblioteca Nacional do Rio de Janeiro (BN), 04,04, 008.

${ }^{67}$ Resposta de Luís de Vasconcelos e Sousa à carta de Martinho de Melo e Castro recebida em 1786. BN 04,04, 008 .

${ }^{68}$ Observaçôes do vice-rei d. Fernando José de Portugal ao Regimento de Roque da Costa Barreto de 23 de janeiro de 1677. Apud AVELLAR, Hélio de Alcântara. História administrativa do Brasil. op. cit., p. 294.
} 
tendência crescente no Setecentos de que os ofícios intermédios fossem concedidos em regime temporário, o que ocorreu não apenas nos territórios ultramarinos. Na listagem que se fez no final do século XVIII dos ofícios das quatro Comarcas da Província do Trás-os-Montes, ${ }^{69}$ por exemplo, no que concerne aos cargos intermédios, independentemente das terras em questão serem régias ou senhoriais, cerca de 70\% estavam sendo servidos de forma trienal.

Com base nessas listas é possível defender que a oposição ao regime de propriedade de ofícios, que teria emergido com maior ênfase no período pombalino, alterou de fato a tipologia dos provimentos dos ofícios intermédios na monarquia portuguesa? As fontes referidas (normativas ou não) nos permitem pensar afirmativamente e, mais uma vez, motivados pelos estudos acerca da monarquia hispânica, ${ }^{70}$ somos tentados a saber se também na monarquia lusa fez-se uso de alguma política de desapropriaçáo. ${ }^{71}$

Para além da conhecida incorporação do ofício de correio-mor no final do século XVIII, ${ }^{72}$ encontramos apenas uma fonte, relativa ao ofício de provedor e feitor-mor da $\mathrm{Al}$ fândega de Lisboa, pertencente a d. Rodrigo António de Noronha e Meneses, de $1757 .^{73} \mathrm{~A}$ excepcionalidade desse tipo de contrato, que também envolveu uma soma de dinheiro, não pode ser explicada apenas porque o ofício foi extinto. Durante todo o Antigo Regime, os titulares e também os oficiais providos temporalmente deveriam ser compensados pelo monarca quando afastados de seus ofícios sem causa justa, quando seus rendimentos sofriam um decréscimo e, tal como no caso anterior, quando o cargo era extinto. ${ }^{74} \mathrm{O}$ que justifica a raridade do contrato de desapropriação que envolveu Noronha e Meneses é a importância social do protagonista mas, sobretudo, o fato de a propriedade deste ofício de elevado status ter sido comprada ainda no século XVII.

O dinheiro permitiu, em alguns casos, o acesso à propriedade ou à serventia dos ofícios (sobretudo intermédios), e sobre essa questão já nos debruçamos com maior ênfase em outros trabalhos aqui citados. $\mathrm{O}$ que surpreende é que o dinheiro tenha garantido aos oficiais um elevado poder de persuasão frente aos tribunais régios na defesa de seus interesses e di-

\footnotetext{
${ }^{69}$ MENDES, José Maria Amado. Trás-os-Montes nos fins do século XVIII, segundo um manuscrito de 1796. Coimbra: Instituto Nacional de Investigação Científica, 1981.

${ }^{70}$ LÓPEZ DÍAZ, Maria. Legislación y doctrina de los oficios en España: el proceso de (re)incorporación a la Corona. In: STUMPF, Roberta; CHATURVEDULA, Nandini (Orgs.), op. cit., p. 213-236.

${ }^{71}$ Juridicamente, a desapropriação por utilidade pública surgiu apenas no final do século XVIII, o que reforça a ideia, aqui subjacente, de que as esferas público/privada foram ganhando contornos distintos, e desvinculando-se. LEITE, Solidónio. Desapropriação por utilidade pública. Rio de Janeiro: Imprensa Gutenberg, 1903. Comentário ao regulamento de 1903, que modificou e consolidou as leis em vigor: seguido do texto das mesmas leis.

${ }^{72}$ NETO, Margarida Sobral. Os correios na Idade Moderna. In: . (Coord.). As comunicaçôes na Idade Moderna. Lisboa: Fundação Portuguesa das comunicaçōes, [S.d.]. p. 47.

${ }^{73}$ ANTT/Casa Real, Núcleo Antigo 323. Escrituras de venda, quitação e obrigação do ofício de provedor e feitor-mor da Alfândega de Lisboa, comprado pelo rei d. José I a d. Rodrigo António de Noronha e Meneses.

${ }^{74}$ Sobre o tema: HESPANHA, António Manuel. História das instituiçóes. op. cit., p. 327-328.
} 
reitos. ${ }^{75}$ Os súditos que arremataram as serventias de ofícios americanos a partir de 1741, por exemplo, com muita recorrência invocavam o fato de terem despendido dinheiro para dar solidez às mais diferentes reivindicaçóes, quase sempre acatadas. $\mathrm{O}$ escrivão da ouvidoria geral da Comarca de Sabará, Capitania de Minas Gerais, que em 1752 comprara a serventia do ofício por 22 contos e 200 mil réis, foi compensado pelo rei pela queda de seus rendimentos com a prorrogação da serventia por mais sete meses. ${ }^{76} \mathrm{~A}$ recompensa não era significativa, como não fora a de muitos que se viram prejudicados e solicitaram alguma espécie de compensação. De qualquer forma, em se tratando de direito dos oficiais, o argumento da compra era juridicamente insuperável. Outro exemplo é o do proprietário escrivão da câmara de Coimbra que, repleto de dívidas, em 1757, foi protegido de uma suposta execução do ofício por tê-lo adquirido mediante dinheiro. ${ }^{77}$

A desapropriação de ofícios não parece ter sido uma prática comum no reinado josefino ou ao menos é o que se pode dizer frente à falta de registros que comprove a sua ocorrência. Por outro lado, tampouco nos parece seguro afirmar que as medidas contrárias à hereditariedade dos ofícios tivessem tido consequências efêmeras. É verdade que logo no primeiro ano do reinado de d. Maria um aviso de 1777 dizia "para se consultarem os requerimentos dos filhos, ou filhas, que ficarem de proprietários encartados em ofícios"78 e que em novembro de 1795 este direito foi estendido a mais um grau na descendência, desta vez "para se consultarem requerimentos de netos de proprietários encartados, e em que se peça a mercê dos mesmos ofícios" ${ }^{79}$ Ainda na proximidade do ano de 1805, é o jurista Lobão quem afirmava que via, “...por novas graças continuadas aos filhos dos proprietários beneméritos a sucessão dos ofícios”. ${ }^{80}$

Somente uma pesquisa em fontes relativas aos provimentos no século XIX permitirá chegar a uma conclusão mais segura sobre como este processo de transição do Antigo Regime ao Liberalismo modificou as modalidades de provimento de ofícios públicos. De qualquer forma, a se tomar a letra a primeira e efêmera Constituição portuguesa de 1822, eram os "talentos e as virtudes" os únicos critérios para que os portugueses fossem admitidos aos cargos públicos, ${ }^{81}$ sendo que, tal como expresso no artigo 13 , " "os ofícios públicos não são de propriedade de pessoa alguma...”.

\footnotetext{
75 Ainda que com alguma excepcionalidade, isto já se verifica no século XV, como no caso que envolveu em 1476 o proprietário vitalício do ofício de escrivão das sisas da cidade de Coimbra. ANTT/Chancelaria d. Afonso V. Livro 6, f. 112. Apud BRITO, Isabel C. de. A burocracia régia tardo-afonsina: A administração central e seus oficiais em 1476. Dissertação (Mestrado em História) - Programa de Pós-Graduação da Faculdade de Letras da Universidade do Porto, 2001. v. I, p. 82.

${ }^{76}$ ANTT/Chancelaria Régia, d. José. Livro 2, f. 6v.

${ }^{77}$ Resolução de 30 de agosto de 1757. "O rei não poderia remover os oficiais a não ser no caso de se certificar (...) de que o oficial servia mal, por culpa ou dolo. Mesmo assim, esta possibilidade náo existiria no caso dos ofícios vendidos". HESPANHA, António Manuel. As vésperas do Leviathan. op. cit., p. 713.

${ }^{78}$ Aviso de 3 de setembro de 1777.

${ }^{79}$ Aviso de 20 de novembro de 1795.

${ }^{80}$ LOBÃO, Manuel D’Almeida e Sousa. Notas de uso prático e críticas... Parte II, op. cit., p. 409-410.

${ }^{81}$ Constituição portuguesa de 1822, título 1o, capítulo único, Artigo 12‥
} 
As fontes normativas nos servem de referência e modelo para entender as realidades, tal como serviam aos homens da época. Mas nem sempre é possível se fiar apenas em seu teor. Diversificando as fontes percebemos que, como é o caso para o tema aqui proposto para análise, as práticas político-administrativas eram de fato muito mais complexas, porque envolviam, como sabemos, também os indivíduos e as redes que se estabeleciam entre eles. De qualquer forma, os termos podiam ir se modificando, mas a verdade é que, mesmo sem nos determos em uma análise quantitativa, não é difícil notar as continuidades. Em 1823, para citar o derradeiro exemplo, foi concedida a "mercê da supervivência da propriedade do ofício de escrivão da provedoria da Câmara de Lamego, ao filho primogênito do anterior proprietário". 82

A tipologia do provimento dos ofícios civis no Antigo Regime português ${ }^{83}$

\begin{tabular}{|c|c|c|c|}
\hline Cargos/ofícios & $\begin{array}{c}\text { Tempo de serviço } \\
\text { e modalidade de } \\
\text { provimento }\end{array}$ & $\begin{array}{c}\text { Local de } \\
\text { provimento }\end{array}$ & Outros \\
\hline $\begin{array}{c}\text { Cargos superiores da monarquia: } \\
\text { Presidência dos tribunais } \\
\text { Vice-reis } \\
\text { Governadores das armas } \\
\text { Governadores de capitania } \\
\text { Outros cargos importantes da } \\
\text { monarquia: } \\
\text { Capitães-mores } \\
\text { Corregedores/ouvidores } \\
\text { Provedores de comarca } \\
\text { Juízes de fora } \\
\text { Provedores da Fazenda Real } \\
\text { Secretários de Governo }\end{array}$ & $\begin{array}{c}\text { concessão precária } \\
\text { (temporária) } \\
\text { ou concessão perpétua } \\
\text { (propriedade) }\end{array}$ & Lisboa & $\begin{array}{l}\text { Remunerados } \\
\text { Nobilitantes }\end{array}$ \\
\hline $\begin{array}{l}\text { Ofícios camarários: } \\
\text { Vereadores, } \\
\text { juízes ordinários, } \\
\text { procuradores... }\end{array}$ & $\begin{array}{l}\text { concessão precária } \\
\text { (temporária) } \\
\text { Normalmente } 1 \text { ano }\end{array}$ & $\begin{array}{l}\text { Localmente } \\
\text { (sujeitos à } \\
\text { confirmação) }\end{array}$ & $\begin{array}{l}\text { Não } \\
\text { Remunerados } \\
\text { Nobilitantes }\end{array}$ \\
\hline $\begin{array}{l}\text { Ofícios eleitos pela Câmara: } \\
\text { Porteiros, guarda-livros, Síndicos } \\
\text { Solicitadores... }\end{array}$ & $\begin{array}{c}\text { concessão precária } \\
\text { (temporária) } \\
\\
\text { concessão precária } \\
\text { (temporária) } \\
\text { ou concessão perpétua } \\
\text { (propriedade) }\end{array}$ & Localmente & $\begin{array}{c}\text { Não } \\
\text { remunerados } \\
\text { Não davam } \\
\text { nem tiravam } \\
\text { nobreza }\end{array}$ \\
\hline
\end{tabular}

(continua)

\footnotetext{
${ }^{82}$ ANTT/Registo Geral de Mercês, d. João VI. Livro 18, fl. 55.

${ }^{83}$ Tipologia que visa simplificar e que não tem a pretensão de compreender todos os ofícios.
} 
(continuação)

\begin{tabular}{|c|c|c|c|}
\hline Cargos/ofícios & $\begin{array}{l}\text { Tempo de serviço } \\
\text { e modalidade de } \\
\text { provimento }\end{array}$ & $\begin{array}{c}\text { Local de } \\
\text { provimento }\end{array}$ & Outros \\
\hline $\begin{array}{c}\text { Ofícios intermédios } \\
\text { Escrivão* } \\
\text { Tabelião (do público judicial e notas) }\end{array}$ & & & $\begin{array}{l}\text { Remunerados } \\
\text { Não davam } \\
\text { nem tiravam } \\
\text { nobreza }\end{array}$ \\
\hline $\begin{array}{c}\text { Meirinho** } \\
\text { *da ouvidoria, dos feitos da Fazenda, } \\
\text { da Alfândega e Almoxarifado, do } \\
\text { judicial e notas, da Provedoria, da } \\
\text { Fazenda... } \\
\text { ** geral da Correição, da Almotaça- } \\
\text { ria, da Alfândega, da Ouvidoria... }\end{array}$ & $\begin{array}{l}\text { concessão precária } \\
\text { (temporária) } \\
\text { ou } \\
\text { concessão perpétua } \\
\text { (propriedade) }\end{array}$ & $\begin{array}{l}\text { Lisboa ou } \\
\text { instituiçóes e } \\
\text { autoridades } \\
\text { locais }\end{array}$ & $\begin{array}{l}\text { Ocasional- } \\
\text { mente remu- } \\
\text { nerados }\end{array}$ \\
\hline
\end{tabular}

\section{Referências bibliográficas}

ALFAIA, João. Carreira. In: GOMES, Henrique Martins; FERNANDES, José Pedro Pereira Monteiro (eds.). Dicionário jurídico da administração pública. Coimbra: Atlântida, 1972. v. II, p. AVELLAR, Hélio de Alcântara. História administrativa do Brasil: a administração pombalina. Brasília: FUNCEP/UnB, 1983.

BARROS, Henrique Gama. História da Administração pública em Portugal nos séculos XII ao $X V$. 2. ed. Lisboa: Sá da Costa, 1956, v. 2.

BICALHO, Maria Fernanda. Ascensão e queda dos Lavre. In: MONTEIRO, Rodrigo B.; FEITLER, Bruno; CALAINHO, Daniela; FLORES, Jorge (Orgs.). Raizes do privilégio: Mobilidade social no mundo ibérico do Antigo Regime. Rio de Janeiro: Civilização Brasileira, 2011.

BRITO, Isabel C. de. A burocracia régia tardo-afonsina: A administração central e seus oficiais em 1476. Dissertação (Mestrado em História) — Programa de Pós-Graduação da Faculdade de Letras da Universidade do Porto, 2001. v. I.

CARDIM, Pedro; MIRANDA, Susana. A expansão da Coroa portuguesa e o estatuto político dos territórios. In: FRAGOSO, João; GOUVÊA, Maria de Fátima (Orgs.). Coleção O Brasil Colonial: 1580-1720. Rio de Janeiro: Civilização Brasileira, 2014. v. 2.

CUNHA, Mafalda Soares da; MONTEIRO, Nuno Gonçalo. Governadores e capitães-mores do império atlântico português nos séculos XVII e XVIII. In: MONTEIRO, Nuno Gonçalo; CARDIM, Pedro; CUNHA, Mafalda Soares da (Orgs.). Optima pars: Elites ibero-americanas do Antigo Regime. Lisboa: Imprensa de Ciências Sociais - ICS, 2005. 
FRAGOSO, João. A nobreza vive em bandos: a economia política das melhores famílias da terra do Rio de Janeiro, século XVII. Algumas notas de pesquisa. Tempo. Revista do Departamento de História da UFF, Niterói, v. 8, n. 15, p. 11-35, 2003.

FURTADO, Júnia Ferreira. Homens de negócio: a interiorização da metrópole e do comércio setecentista. São Paulo: Hucitec, 1999.

GALLO, Alberto. La venalidad de oficios públicos durante el siglo XVIII. In: BELLINGERI, Marco (Coord.). Dinámicas de Antiguo Régimen y orden constitucional: Representación, justicia y administración. Siglos XVIII-XIX. Turim: Otto, 2000.

GROSSI, Paolo. Assolutismo giuridico e diritto privato. Milano: Giuffre, 1998.

. Historia del derecho de propiedad: La irrupción del colectivismo en la conciencia europea. Barcelona: Ariel, 1986.

HERMÁNEZ BENÍTEZ, Mauro. Venalidad de oficios municipales en la Castilla del siglo XVIII: un ensayo de cuantificacions. Chronica Nova, n. 33, p. 95-129, 2007.

HESPANHA, António Manuel. As vésperas do Leviathan: Instituiçôes e poder político. Portugal século XVII. Lisboa, 1986. v. 1.

. História das instituiçôes: Épocas medieval e moderna. Coimbra: Livraria Almedina, 1982.

. Poder e instituiçōes na Europa do Antigo Regime: Coletânea de textos. Lisboa: Fundação Calouste Gulbenkian, 1984, p. 36. In: . História das instituiçôes... Coimbra: Livraria Almedina, 1982.

LEITE, Solidónio. Desapropriação por utilidade pública. Rio de Janeiro: Imprensa Gutenberg, 1903.

LOBÃO, Manuel D’Almeida e Sousa. Notas de uso prático e críticas, adiçōes, ilustraçôes e remissóes sobre todos os titulos e todos os SS do Livro $2^{-}$das Instituiçôes de direito civil lusitano do d. Pascoal José de Melo e Freire. Parte II. Lisboa: Imprensa Nacional, 1836.

LÓPEZ DÍAZ, María; LEIVA, Pilar Ponce. In: ANDÚJAR CASTILLO, Francisco; FELICES DE LA FUENTE, Maria del Mar (Eds.). El poder del dinero: Ventas de cargos y honores en el Antiguo Régimen. Madri: Biblioteca Nueva, 2011.

MACEDO, Deoclécio Leite de. Tabeliães do Rio de Janeiro, $1^{\circ}$ ao $4^{\circ}$ ofício de Notas, Rio de Janeiro: Arquivo Nacional, 2007. (esta é outra referência e deve constar na lista de forma autómona, respeitando a ordem alfabética. MACEDO, antes de MAGALHÃES)

MAGALHÃES, Joaquim Romero. Os nobres da governança da terra. In: MONTEIRO, Nuno Gonçalo; CARDIM, Pedro; CUNHA, Mafalda Soares da (Orgs.). Optima pars: Elites ibero-americanas do Antigo Regime. Lisboa: Imprensa de Ciências Sociais - ICS, 2005.

. Reflexôes sobre a estrutura municipal portuguesa e a sociedade colonial brasileira. In: MAGALHĀES, Joaquim Romero. Concelhos e organização municipal na época moderna. Coimbra: Miunças 1, 2011. 
MENDES, José Maria Amado. Trás-os-Montes nos fins do século XVIII, segundo um manuscrito de 1796. Coimbra: Instituto Nacional de Investigaçáo Científica, 1981.

MELO, Josemar Henrique de. A ideia de arquivo: A secretaria do governo da Capitania de Pernambuco (1687-1809). Tese (Doutorado em Ciências Documentais) — Faculdade de Letras da Universidade do Porto, Porto, 2006.

MONTEIRO, Nuno Gonçalo. Elites locais e mobilidade social em Portugal nos finais do Antigo Regime. Análise social, Lisboa, ICS, n. 147, p. 335-368, 1997.

NETO, Margarida Sobral. Os correios na Idade Moderna. In: . (Coord.). As comunicaçôes na Idade Moderna. Lisboa: Fundação Portuguesa das comunicaçôes, [S.d.].

OLIVAL, Fernanda. As ordens militares e o Estado moderno: Honra, mercê e venalidade (1641-1789). Lisboa: Estar, 2001.

SILVA, Francisco Ribeiro da. Venalidade e hereditariedade dos ofícios públicos em Portugal nos séculos XVI e XVII. Alguns aspectos. Revista do Centro de História da Universidade do Porto, v. 8, p. 203-213, 1988.

SOUSA, Avanete Pereira. A Bahia no século XVIII: Poder político local e actividades económicas. São Paulo: Alameda, 2012.

STUMPF, Roberta G. Venalidade de ofícios e honras na América portuguesa: um balanço preliminar. In: ALMEIDA, Suely de; SILVA, Gian Carlo de M.; SILVA, Kalina V.; SOUZA, George F. C. de (Orgs.). Politicas e estratégias administrativas no mundo Atlântico (séc. XV-XVIII). Recife: Universidade Federal de Pernambuco, 2012.

STUMPF, Roberta G. Formas de venalidade de ofícios na monarquia portuguesa do século XVIII. In: STUMPF, Roberta G; CHATURVEDULA, Nandini (Org.). Cargos e oficios nas monarquias ibéricas (séculos XVII e XVIII): provimento, controlo e venalidade. Lisboa: Centro de História de Além-Mar da Universidade de Lisboa, 2012.

. Os cavaleiros do ouro e outras estratégias nobilitantes nas Minas Setecentistas. Belo Horizonte: Fino Traço, 2014.

STUMPF, Roberta. "Qualidades formais, requisitos efetivos: a imagem do bom servidor régio no Império português do século XVIII”. Comunicação apresentada no IV Encontro internacional de História Colonial, Belém do Pará, 2012.

ZENHA, Edmundo. Os municípios no Brasil: 1532-1700. São Paulo: Instituto Progresso Editorial, 1948. 